\title{
THE HUMANISTIC PSYCHOLOGIST
}

\section{EDITOR}

Christopher M. Aanstoos

Psychology Department, University of West Georgia, Carrollton, GA 30118

\section{CONSULTING EDITORS}

Myron M. Arons University of West Georgia

Carol S. Becker California State University, Hayward

Peter R. Breggin Johns Hopkins University

James F. T. Bugental California Institute of Integral Studies

David J. Cain Chapman University

Scott D. Churchill University of Dallas

P. Erik Craig University of New Mexico

Constance T. Fischer Duquesne University

Eugene $T$. Gendlin University of Chicago

Amedeo P. Giorgi Saybrook Graduate School

Thomas Greening Saybrook Graduate School

Fred Hanna Johns Hopkins University

Jean Houston Foundation for Mind Research

Stanley Krippner Saybrook Graduate School

Arthur W. Lyons Moravian College

Alvin Mahrer University of Ottawa

Fred Massarik University of California, Los Angeles

Bertha Mook University of Ottawa

James Morley Richmond College, London

Clark Moustakas Center for Humanistic Studies

Maureen O'll lara Saybrook Graduate School

Donald Polkinghome University of Southern California

Howard R. Pollio University of Tennessee

Kaisa Puhakka Institute for Transpersonal Psychology

Donadrian L. Rice University of West Georgia

M. Brewster Smith Emeritus, University of California, Santa Cruz

E. Mark Stern lona College

Thomas S. Szasz State University of New York, Syracuse

Roger Walsh University of California, Invine

Nora Weckler Emeritus, California State University, Northridge

Frederick J. Wertz Fordham University

Irvin D. Yalom Stanford University

EDITORIAL ASSISTANT: Courtney Tallman

SUBSCRIPTIONS: The Humanistic Psychologist is published three times per year. Subscriptions are available on a calendar year basis only; the Individual rate is $\$ 20.00$ per year, and the Institutional rate is $\$ 40.00$. All orders outside the U.S. add $\$ 6.00$ for surface delivery or $\$ 15.00$ for air mail delivery. Back issues are available for separate purchase. Send all subscription orders to the Editor.

COPYRIGHT AND PERMISSIONS: 02000 by Div. 32 of the American Psychological Association. Authorization to photocopy items for internal or personal use, or the internal or personal use of specific clients, is granted by Div. 32, provided the fee of \$0.05 per copy per page is paid to Copyright Clearance Center, 222 Rosewood Drive, Danvers. MA 01923. All inquiries concerning copying should be directed to that office (508-750-8400). Access services may use abstracts without permission or payment. 